\title{
ГУМАНИТАРНОЕ СОТРУДНИЧЕСТВО РЕСПУБЛИКИ БЕЛАРУСЬ И ФЕДЕРАТИВНОЙ РЕСПУБЛИКИ ГЕРМАНИЯ
}

\section{Н. Н. КОРОЛЬЧУК}

\section{Брестский государственный университет имени А. С. Пуикина, г. Брест, Беларусь}

Германия оказывает международную техническую помощь Беларуси с 1992 г., сначала в рамках программы ТРАНСФОРМ (1992-1998), а затем Национальной программы для Беларуси, инициированной МОЦ г. Дортмунда, ФРГ. Программа консультационной помощи федерального правительства Германии ТРАНСФОРМ была организована в начале 1990-х годов для стран Центральной и Восточной Европы в целях оказания помощи этим странам в рыночных преобразованиях их экономики.

Проекты программы ТРАНСФОРМ в Беларуси реализованы в следующих областях:

- консультации правительству (приватизация, право, статистика);

- $\quad$ производство (обучение и повышение квалификации специалистов, подготовка консультантов в производственной сфере, организация производства автобусов, осей и седельных прицепов, производство материалов для связи, реструктурирование строительных организаций в г. Мозыре, создание систем аккредитования и сертификации; модельный проект производства автомобилей);

- финансовый сектор (поддержка в обучении и повышении квалификации сотрудников банков и составлении учебных планов, автоматизация белорусских банков);

- сельское хозяйство (создание аграрной консультационной службы в г. Бресте; содействие в выращивании крупного рогатого скота, организация курсов для садоводов);

- социальный сектор (поддержка создания модельного центра занятости в г. Борисове, профессиональная реабилитация инвалидов);

- поддержка предприятий малого и среднего бизнеса (производство одежды; обучение и переподготовка кадров, создание Могилевского технопарка и Центра страхования в г. Минске);

- жилищное строительство (модельный проект жилищно-коммунального хозяйства в г. Лиде, работа над модельным проектом по созданию социальноориентированной жилищно-коммунальной службы в г. Заславле).

Всего за 1992-1998 гг. в рамках программы ТРАНСФОРМ для Беларуси было реализовано более 200 проектов с общим бюджетом свыше 40 млн долл. США. В 2001 г. Федеральное правительство Германии приняло в дополнение к программе ТРАНСФОРМ Программу поддержки Беларуси, которая направлена на оказание содействия развитию гражданского общества в Беларуси, усиление инициативы граждан, поддержку германобелорусского сотрудничества в различных сферах, содействие интеграции Беларуси в общеевропейские структуры.

Программа имела четыре этапа:

1. 2002-2003 гг. - объем финансирования 2,5 млн евро;

2. 2003-2004 гг. -1,5 млн евро;

3. 2005-2006 гг. - 2,5 млн евро;

4. 2007-2008 гг. - 1,5 млн евро.

За первых три этапа было осуществлено около 115 проектов, бюджет которых составлял от 4 тыс. до 50 тыс. евро. Основными приоритетами четвертого этапа Программы явились: экономика и региональное развитие - 34,7\% от выделенных средств; образование $29,9 \%$; социальная сфера - 17,8\%; энергетика и экология $-17,6 \%$. Основными критериями отбора заявок являлись: значимость проекта с учетом потребностей и возможностей страны; целевая группа; распространение (мультипликация) достигнутых в ходе реализации проекта 
результатов. По величине бюджета проекты подразделялись на малые (до 10 тыс. евро) и большие (от 10 тыс. до 50 тыс. евро) [2, с. 18-20].

Активную деятельность проводят немецкие гуманитарные организации, которые работают по таким направлениям, как сохранение памяти жертв Второй мировой войны, поддержка бывших жертв и свидетелей Холокоста и Второй мировой войны. Особое значение на данном этапе имеет реализация совместного проекта по созданию в Беларуси мемориального комплекса «Тростенец» на месте одноименного лагеря смерти как европейского символа памяти жертв преступлений национал-социализма [5].

Важную роль в этом направлении играет Volksbund Deutsche Kriegsgrä berfürsorge e.V. («Народный союз Германии по уходу за военными захоронениями»). По поручению федерального Правительства он занимается сбором данных о немецких воинских захоронениях за рубежом, работой по их сохранению и уходу за ними. Народный Союз поддерживает родственников в вопросах ухода за военными могилами, консультирует общественные организации и отдельных лиц, осуществляет международное сотрудничество в области ухода за воинскими захоронениями и содействует организации международных молодежных встреч на местах захоронений погибших и умерших. Так например, Volksbund 1 октября 2005 г. открыл кладбище в г. Береза. На сегодняшний день здесь похоронено более 18700 человек. Всего на территории Беларуси при помощи Народного союза Германии создано 36 кладбищ, где захоронены солдаты периода Первой и Второй мировых войн [3; 16].

Представительство общественно полезного общества с ограниченной ответственностью «Internationales Bildungs- und Begegnungswerk gemeinnützige GmbH» (Международная и образовательная общественная организация) в ФРГ создано с целью привлечения безвозмездной иностранной помощи для укрепления мира, согласия и дружественных связей между народами, а также устранения конфликтов на социальной и этнической почве. Основными направлениями деятельности Представительства являются: программа поддержки Беларуси (ППБ), история и культура памяти. Программа поддержки Беларуси финансируется из средств Федерального министерства экономического сотрудничества и развития Германии. В рамках 8-го этапа ППБ, который закончился в марте 2019 г., поддержано 22 партнерских проекта [7, с. 11; 14].

Второе направление деятельности Представительства производится на базе Исторической мастерской, в рамках которой осуществляется поддержка бывших жертв и свидетелей Холокоста и Второй мировой войны, что способствует сохранению и передаче памяти современным поколениям. При непосредственном участии «Исторической мастерской» проводятся такие мероприятия, как, например, передвижная выставка «Лагерь смерти Тростенец. История и память», которая начала свою деятельность с августа 2014 г. Задачей выставки является укоренение в общественном сознании Малого Тростенца как места преступлений нацизма [4].

Организацией, оказывающей поддержку жертвам национал-социализма, является фонд «Память, ответственность, будущее» (Stiftung Erinnerung, Verantwortung, Zukunft). Фонд оказывает финансовую поддержку проектам, направленным на предоставление жертвам произвола национал-социализма достойного социального и медицинского обеспечения и расширение диалога поколений. По состоянию на 2019 г. Беларусь получила финансирование в размере 325 млн евро, 120000 человек получили выплаты (пособия получали люди, чей труд эксплуатировался в концентрационном лагере или закрытом гетто, а также люди, которые были депортированы из своих родных земель в Германии, или на территориях, оккупированных Германией и должны были принудительно работать в местах лишения свободы). В общей сложности фондом «Память, ответственность, будущее» на территории Беларуси осуществляется около 240 проектов [15].

Чтобы стимулировать диалог поколений с жертвами нацизма, фонд «Память, ответственность, будущее» способствует использованию молодых добровольцев в гуманитарных проектах. Ассоциация Aktion Sühnezeichen Friedensdienste (Служба примирения действий ради мира - ARSP) отправляет молодых людей, которые участвуют в проектах фонда 
в Польше, России, Беларуси, Украине и Чешской Республике в течение двенадцати месяцев. Основная задача волонтеров заключается в поддержке выездных служб и учреждений для пожилых людей: они сопровождают пожилых людей в повседневной жизни, оказывают практическую помощь и предлагают развлекательные мероприятия. У волонтеров есть возможность провести интервью с жертвами национал-социализма. Цель ассоциации состоит в том, чтобы привлечь внимание молодых добровольцев к проблемам пожилых людей. В настоящее время в Германии насчитывается 20 международных добровольцев. Кроме того 180 добровольцев работают с ASF в Беларуси, Бельгии, Франции, Великобритании, Израиле, Нидерландах, Норвегии, Польше, России, Чехии, Украине и США [10; 14].

Программа Treffpunkt Dialog фонда «Память, ответственность, будущее» предназначена для белорусских, российских и украинских организаций, которые стремятся улучшить условия жизни пожилых людей в своих странах. Цель финансирования содействие в оценке достижений на протяжении всей жизни и социальное признание жертв нацизма. Целевая группа программы финансирования - люди, пострадавшие от националсоциализма, такие как бывшие узники концлагерей и гетто, бывшие нацистские подневольные работники, советские военнопленные и другие.

Гуманитарное взаимодействие Беларуси и Германии особенно велико в сфере преодоления последствий аварии на Чернобыльской атомной электростанции. Чернобыльская катастрофа 1986 г. вызвала в Германии значительную волну солидарности и готовности оказать поддержку пострадавшим регионам Республики Беларусь. В Германии действуют более 400 чернобыльских инициатив, которые вносят существенный вклад в преодоление последствий Чернобыльской катастрофы. Германия традиционно лидирует среди стран, оказывающих Беларуси содействие в этой сфере. Ежегодно из ФРГ поступает до $20 \%$ от общего объема иностранной гуманитарной помощи, около трех тысяч белорусских детей проходят курс оздоровления в Германии.

Важное значение для Беларуси и мирового сообщества имели научные исследования, направленные на рассмотрение и анализ проблем воздействия аварии на человека и окружающую среду. Белорусские и германские ученые и специалисты приняли активное участие в работе крупных конференций и симпозиумов, посвященных Чернобыльской катастрофе, например белорусско-германской партнерской конференции «Чернобыль предостерегает» в немецком городе Гезек (2016), «30 лет со дня Чернобыля (Брюссель) $[8$, с. 62; 14]. Также было реализовано более 15 научно-исследовательских и экспериментальных проектов по радиологии, радиационной медицине, онкоэпидемиологическому мониторингу результатов катастрофы, биологической дозиметрии, развитию компьютерных систем для прогнозирования радиоэкологических результатов аварии на АЭС, разработке стратегии дезактивации.

Одним из важнейших аспектов в преодолении последствий Чернобыльской катастрофы стало создание специализированных медицинских центров и оснащение их медицинским оборудованием. В этом направлении наиболее значимым стал результат сотрудничества Министерства здравоохранения Беларуси и Радиологического института имени Отто Хуга в Мюнхене - создание центра по заболеваниям щитовидной железы в Гомеле. Крупным проектом было открытие детского реабилитационно-оздоровительного центра «Надежда» в 1994г., созданного в равных долях белорусской и немецкой стороной [8, c. 63]. Передача опыта, технологий и знаний, повышение квалификации медицинских и научных работников осуществлялись в рамках стажировок белорусских врачей в немецких медицинских учреждениях. Только по линии общественной организации «Помощь детям Чернобыля» (Ганновер) стажировку в ФРГ прошли около 100 белорусских врачей.

Огромный вклад немецкие общественные организации и семьи внесли в оздоровление детей из районов, подвергшихся воздействию аварии на ЧАЭС. Только организация «Помощь детям Чернобыля» за 6 лет приняла на оздоровление 7 тыс. детей [17]. По оценкам немецкой стороны в период с 1990 по 2001 г. на оздоровлении побывали около 122 тыс. детей. По оценкам белорусской стороны с 1990 по 2006 г. - 150 тыс., только в 2005 г. - около 10 тыс. [9]. 
За последние пять лет за счет иностранной безвозмездной помощи выехало на оздоровление за рубеж 131766 детей, в том числе в Германию - 24856 детей или 18,9 \% [1, с. 37; 62].

Для оценки значения сотрудничества в области отдыха и оздоровления детей большой интерес представляют результаты социологических исследований, проведенных в 1995 г. в Беларуси службой «Открытое мнение». Около 67 \% опрошенных, высказывая свое мнение в отношении различных форм гуманитарной помощи, выделили в качестве важнейшего направления сотрудничество в сфере организации отдыха и оздоровления детей за рубежом [8, с. 64].

Белорусские и немецкие государственные и общественные организации, посольства обеих стран, деятели культуры и искусства проделали большую работу с целью информирования и формирования общественного мнения белорусского и немецкого народа о проблеме преодоления катастрофы в Чернобыле. С этой целью проводятся различные информационные мероприятия, благотворительные культурные акции, выставки, конференции, театральные и музыкальные представления.

В Беларуси в этом направлении активно работают институт имени Гёте и международный образовательный центр имени Й. Рау. Гёте-Институт готовил серию мероприятий к 10-летию аварии на ЧАЭС: театральный проект «Помни», фотовыставки «Эхо молчания», показ документального фильма Ю. Хощеватского «Оазис», который был снят при активном участии Германии.

Минский международный образовательный центр имени Й. Рау совместно с Дортмундским международным образовательным центром (МОЦ) и фондом «Меркатор» и европейским объединением «EUSTORY» создали в 2010 г. проект «25 лет после Чернобыля. Путь к трансграничной культуре памяти», состоящего из трех частей: Люди-Места-Европейская солидарность. Проект направлен на поиск информации и исследование документации о трагедии в Чернобыле, повышение интереса молодежи к дискуссии об аварии и к проблемам окружающей среды (изменение климата, энергоснабжение, защита окружающей среды), а также на оказание помощи пострадавшим в Беларуси и Украине [4; 5, с. 65].

Таким образом, можно сделать вывод, что гуманитарное сфера - одна из самых приотритетных направлений развития белорусско-германских взаимоотношений, что обусловлено историческими факторами. Обе страны ведут активный диалог в сфере сохранения исторической памяти событий Второй мировой войны, Холокоста и аварии на Чернобыльской АЭС.

\section{Литература}

1. Борисевич, Н. Я. Беларусь и Чернобыль : 27 лет спустя / Н. Я. Борисевич, О. В. Соболев; под ред. В. В. Ржеуцкой. - Минск, 2013. - 104 с.

2. Доноры международной технической помощи Республике Беларусь. Справочник. / Сост. В. Ф. Белицкий - Минск: Ковчег, 2009. - 105 с.

3. Иностранное кладбище немецких военнослужащих времен Второй мировой войны [Электронный ресурс] // Государственное учреждение культуры «Березовская районная библиотека». - Режим доступа : https://bereza-cbs.by/inostrannoe-kladbische-nemeckihvoennoslujaschih-vremen-vtoroy-mirovoy-voyny/. - Дата доступа : 19.03.2020.

4. Историческая мастерская года [Электронный ресурс]. - Режим доступа : http://gwminsk.com/. - Дата доступа : 28.04.2020.

5. Метеж, О. А. Белорусско-германские проекты по преодолению Чернобыльской катастрофы (конец XX - начало XXI в.) / О. А. Метеж // Весці Нацыянальнай Акадэіміі навук Беларусі. - Минск, 2013. - С. 62-67.

6. Посольство Республики Беларусь в Федеративной Республике Германия [Электронный pe-cypc]. - Режим доступа : http://germany.mfa.gov.by/ru/embassy/news/ e9b3cc0d48d1734d.html. - Дата доступа : 12.11.2019. 
7. Программа поддержки Беларуси Федерального Правительства Германии 8-го этапа (2016-2019) «Преодолевая границы» [Электронный ресурс]. - Режим доступа : http://ibbd.by/programma-podderzhki-belarusi/. - Дата доступа : 03.02.2020.

8. Русакович, А. В. Белорусско-германское сотрудничество в 1990-х гг. по преодолению последствий Чернобыльской катастрофы / А. В. Русакович // Белорусский журнал международного права и международных отношений. - 1999. - № 4. - С. 59-64.

9. "Чернобыльские" дети будут ездить на оздоровление в Германию по бесплатным визам [Электронный ресурс] // Белорусские новости. - Режим доступа : https://naviny.by/node/107934/talk. - Дата доступа : 11.12.2019.

10. Aktion Sühnezeichen Friedensdienste [Electronic resource]. - Mode of access : https://www.asf-ev.de/ueber-uns/. - Date of access : 18.11.2019.

11. Arndt, M. Von der Todeszone zum Strahlen-Mekka? Die Erinnerung an die Katastrophe von Tschernobyl in Belarus, der Ukraine und Russland [Electronic resource] / M. Arndt // Zeitgeschichte. - Mode of access : https://zeitgeschichte-online.de/themen/von-der-todeszonezum-strahlen-mekka. - Date of access : 17.01.2020.

12. Belarus. Beziehungen zu Deutschland. Bilaterale Beziehungen [Electronic resource] // Auswärtige Amt. - Mode of access : https://www.auswaertiges-amt.de/de/aussenpolitik/ laender/belarus-node/bilaterale-beziehungen/201910. - Date of access : 26.10.2019.

13. Informationen $\mathrm{zu}$ den Auszahlungen an ehemalige Zwangsarbeiter [Electronic resource] // Stiftung EVZ. - Mode of access : https://www.stiftung-evz.de/fileadmin/ user_upload/EVZ_Uploads/Stiftung/Zahlen_und_Fakten/infos-auszahlungen-de.pdf. - Date of access : 16.04.2020.

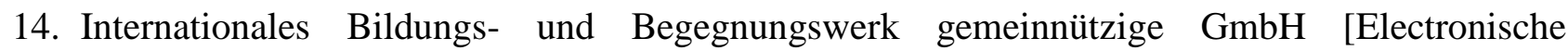
ressourse]. - Mode of access : http://ibb-d.by/de/ueber-repraesentanz/. - Date of access : 21.12.2019.

15. Stiftung Erinnerung, Verantwortung, Zukunft [Electronic resource]. - Mode of access : https://www.stiftung-evz.de/stiftung/geschichte.html. - Date of access : 27.01.2020.

16. Volksbund [Electronic resource]. -Mode of access : https://kriegsgraeberstaetten.volksbund.de. - Date of access : 01.03.2020.

17. 10 Jahre Tschernobyl - 5 Jahre Internationale Solidarität. Berlin: Stiftung West-Ostliche Begegnungen, 1996. $-60 \mathrm{~s}$.

В статье рассматриваются основные аспекты, формы гуманитарного сотрудничества Республики Беларуси и Федеративной Германии. Рассмотрены основные достижения сотрудничества, организации, которые являются активными участниками взаимодействия, изучена их работа в области сохранения памяти жертв Второй мировой войны, поддержки бывших жертв и свидетелей Холокоста и Второй мировой войны, преодоления последствий аварии на Чернобыльской АЭС.

The article examines the main aspects, forms of humanitarian cooperation between the Republic of Belarus and Federal Germany. The main achievements of cooperation, organizations that are active participants in interaction are considered, their work in the field of preserving the memory of the victims of the Second World War, supporting the former victims and witnesses of the Holocaust and World War II, overcoming the consequences of the Chernobyl accident are examined. 